DOI: https://doi.org/10.47405/mjssh.v5i10.500

\begin{tabular}{|c|c|}
\hline 4 & Malaysian Journal of Social Sciences and Humanities (MJSSH) \\
\hline $\begin{array}{l}\text { Malaysian Journal of } \\
\text { Social sciences and }\end{array}$ & Volume 5, Issue 10, October 2020 \\
\hline (MJ-SSH) & e-ISSN : 2504-8562 \\
\hline & $\begin{array}{l}\text { Journal home page: } \\
\text { www.msocialsciences.com }\end{array}$ \\
\hline
\end{tabular}

\title{
Parinang: Ritual Perubatan Masyarakat Iranun di Daerah Kota Belud, Sabah
}

\author{
Mohd Asnari Taim¹, Lokman Abdul Samad' ${ }^{1}$, Asmiaty Amat ${ }^{1}$ \\ 1Pusat Penataran Ilmu dan Bahasa, Fakulti Sains Sosial dan Kemanusiaan, Universiti Malaysia Sabah (UMS) \\ Correspondence: Mohd Asnari Taim (westnari94@gmail.com)
}

\begin{abstract}
Abstrak
Tumpuan penyelidikan ini menjurus terhadap ritual perubatan parinang yang terdapat dalam masyarakat Iranun. Masyarakat Iranun di daerah Kota Belud mempunyai pelbagai jenis upacara ritual termasuk ritual perubatan yang menjadi warisan turun temurun. Objektif utama dalam penyelidikan ini ialah mendokumentasikan sepenuhnya warisan perubatan tradisional dalam kalangan masyarakat Iranun. Makalah, tulisan ini ditulis berasaskan kajian lapangan yang dilakukan di kampung Rampayan Laut, Kota Belud. Temu bual dilakukan terhadap salah seorang panai (bomoh) yang masih hidup dan masih mengamalkan ritual perubatan ini. Ritual parinang merupakan ritual penyembuhan yang melibatkan alam ghaib. Masyarakat Iranun mempercayai bahawa dengan izin Allah swt, alam ghaib mampu membantu alam manusia menyembuhkan penyakit yang meibatkan campur tangan makhluk halus. Ritual ini secara tidak langsung mempamerkan penggunaan dan pengamalan budaya perubatan tradisi yang terdapat dalam kepercayaan masyarakat Iranun.
\end{abstract}

Kata kunci: perubatan tradisional, ritual penyembuhan, Iranun, budaya, Parinang

\section{Parinang: Medical Ritual of Iranun Community in Kota Belud District, Sabah}

\begin{abstract}
The focus of this research leads to Parinang medical ritual in Iranun community. Iranun community in Kota Belud district has various types of ritual ceremony including medical rituals that became a legacy passed down through generations. The main objective of this research is to fully document the traditional medicine heritage among the Iranun community. Therefore, this writing is written based on field research conducted at Rampayan Laut village, Kota Belud. Interview was conducted on one of the Panai (shaman) that is still alive and practicing this medical ritual. Parinang ritual is a healing ritual involving the supernatural. The community of Iranun believes that with permission of Allah S.W.T., the supernatural is capable of helping the human realm to cure diseases involving the intervention of supernatural beings. This ritual indirectly exhibits the uses and practices of traditional medicine culture in Iranun community belief.
\end{abstract}

Keywords: traditional medicine, healing ritual, Iranun, Parinang 


\section{Pengenalan}

Berdasarkan maklumat Hj. Masrin $\mathrm{Hj}$ Hasin (2010), persejarahan awal Iranun dapat ditelusuri dengan melihat kewujudan penempatan awal yang dikenali sebagai Marampayan di Kota Belud. Setelah itu, muncul perkampungan seperti Rampayan Laut, Rampayan Ulu, dan Nanamun. Rampayan merupakan penempatan yang terletak di muara sungai. Sebelum kedatangan Inggeris, terdapat empat kawasan dalam daerah Tempasuk yang diletakkan di bawah naungan orang Iranun. Kawasannya ialah Marampayan, Keguraan, Kuala Pandasan dan Sungai Bakal. Keempat-empat kawasan ini mempunyai pemerintahnya tersendiri. Marampayan diketuai oleh Pangeran Paduka, Keguraan diketuai oleh Raja Muda Malaik, Sungai Bakal oleh Sultan Mamantar dan Kuala Pandasan di bawah kekuasaan Sultan Adil.

Melihat kepada pengistilahan, Iranun berasal daripada kata dasar ranun yang bermaksud perasaan kasih sayang, cinta, rindu dan keprihatinan (Datu Bandira, 1992:3). Apabila ditambah dengan imbuhan 'i', maka terjadi gabungan kata Iranun yang bermaksud "berkasih-kasihan". Melalui catatan McKaughan (1996) yang dipetik daripada Macaraya (1993: 45) memberikan tafsiran istilah Iranun yang bermaksud "tercinta" sempena nama tradisional tanah air rakyat Maranao di Selatan Filipina. Kalau menurut catatan SIL (2002: 130), maksud ranun ialah simpati, kasih dan cinta.

Dalam etnik ini, masyarakat Iranun tidak ketinggalan dengan kepelbagaian amalan dan perubatan tradisi. Etnik Iranun ini masih mempunyai amalan dan perubatan tradisi yang masih diamalkan sehingga kini. Amalan perubatan tradisi ini dipraktikkan dengan dua kaedah iaitu perubatan menggunakan herba semula jadi dan ritual mengubati pesakit.

Bagi masyarakat Iranun masih terdapat pelbagai perkara yang bersifat mistik. Perkara ini sering saja dikaitkan dengan kepercayaan atau pengaruh animisme yang terdapat dalam corak kehidupan masyarakat etnik Iranun. Dalam era modenisasi ini, meskipun telah diperkenalkan konsep perubatan moden, akan tetapi masyarakat Iranun tetap meyakini bahawa perubatan ritual Parinang masih mampu untuk membantu memberi kesembuhan terhadap penyakit yang melibatkan alam ghaib. Bagi masyarakat Iranun, ritual Parinang perlu dilakukan dengan rapi tanpa dipersendakan kerana ritual ini melibatkan semangat halus atau kuasa spiritual. Disebabkan itu, perubatan ritual ini masih digeruni oleh masyarakat Iranun sehingga kini dan tidak boleh dilakukan tanpa tujuan serta diperolokkan. Walau bagaimanapun, dalam konteks penyelidikan ini, penulis hanya membincangkan isu ritual Parinang ini untuk pendokumentasian budaya pengubatan ritual Parinang dalam kalangan masyarakat Iranun.

\section{Tinjauan Perpustakaan}

Melalui tinjauan perpustakaan, Mohd Kipli Abdul Rahman (2015) ada membincangkan mengenai ritual Bebayuh dalam budaya Melanau yang ditandai dengan penyembahan, pengorbanan dan tabu sebagai simbol kepada perilaku pelakunya. Pengamal ritual Bebayuh ini percaya bahawa dunia fizikal dipengaruhi oleh alam metafizikal khusunya dunia yang dihuni oleh makhluk lain, mitos dan semangat yang dikaitkan dengan nenek moyang. Dengan kepercayaan bahawa dunia ini dikongsi dengan makhluk-makhluk lain, maka sesajian dan ritual Bebayuh ini dipersembahkan untuk memohon bantuan sewaktu proses pengubatan dijalankan. Dalam kajian ini mendapati bahawa ritual Bebayuh mempunyai peranan penting dalam kehidupan masyarakat Melanau, khususnya cara alternatif perubatan dan penyembuhan penyakit yang kemudiannya disesuaikan semula dengan tujuan persembahan kebudayaan.

Dalam kalangan masyarakat Kadazan Penampang di Sabah pula, terdapat ritual pengubatan yang dikenali sebagai Monogit. Ritual Monogit ini dilakukan semasa menjamu semangat padi. Ritual ini dilakukan untuk memastikan semangat penjaga rumah (miontong) berada dalam keadaan yang tenang. Ritual tersebut dilakukan oleh bobohizan dan diketuai oleh bohungkitas. Ritual ini diiringan dengan paluan gandang dan sompogogungan (mengandungi 6 biji gong) serta tarian Sumazau. Gabungan paluan gandang dan sompogogungan ini dipercayai mampu menghidupkan semangat dan roh di 
samping bacaan inait (mantera) oleh bobohizan. Ritual ini dilhat penting dan berkesan sebagai gabungan ritual pengubatan dengan kehadiran bobohizan dan bohungkitas, pamanta (makanan), paluan gandang, irama sompogogungan serta tarian sumazau secara jelas dilihat memperkuatkan tradisi itu sebagai sebuah ritual seni persembahan pengubatan (Hanafi Hussin, 2006).

\section{Kaedah Kajian}

Penyelidikan awal kajian ini dijalankan di kampung Rampayan Laut, Kota Belud Sabah. Bermulanya kajian mengenai Tarian Sumaranun. Penulis menggunakan kaedah temu bual, pemerhatian dan ikut serta. Penyelidikan ini sukar untuk diteruskan akibat tiada pesakit dan tiada informan yang mempunyai kemahiran terhadap perubatan ritual ini. Mujur ketika itu, sibuk membicarakan hal ini kepada seorang responden, makanya penulis dibawa ke kawasan Tapukan sekitar kawasan kampung Rampayan Laut untuk bertemu dengan seorang informan yang mempunyai kepakaran dan kemahiran mengenai perubatan ritual ini. Namun, penulis tidak dapat menyaksikan secara langsung bentuk perubatan ritual Parinang yang dimaksudkan. Hal ini disebabkan, menurut informan perubatan ritual ini bukanlah perubatan yang sewenang wenangnya dilakukan kerana ini melibatkan alam ghaib (makhluk halus). Justeru itu, dalam penyelidikan ini, penulis dan informan mempunyai kata sepakat untuk melakonkan semula bentuk perubatan ritual dijalankan. Melalui lakonan semula ini, penulis bertanyakan beberapa soalan dan informan menjelaskan kepada penulis sambil menunjukkan caranya. Segala maklumat dicatatkan dan dirakam sebagai bukti pendokumentasian.

\section{Latar Belakang Perubatan Ritual Etnik Iranun: Parinang}

Parinang merupakan perubatan ritual dalam masyarakat Iranun sejak dulu lagi. Menurut Hjh Pandian Sulaiman (70), Parinang memberi maksud menyeru makhluk halus, jin atau memanggil hantu. Berdasarkan kepercayaan masyarakat Iranun, ritual Parinang merupakan sejenis rawatan atau ikhtiar untuk merawat pesakit yang berpunca daripada pengaruh makhluk halus atau kuasa ghaib. Biasanya perubatan ini akan diketuai oleh seorang Panai (si bomoh). Panai ini yang berfungsi untuk mengetuai perubatan Parinang ini dan menyeru beberapa makhluk halus. Dalam proses ritual ini, Si Panai akan membuat Bpangalai setelah makhluk halus yang diseru telah merasuki tubuhnya. Umumnya, dapat digambarkan perubatan ritual ini melibatkan langkahan tarian sebagai langkah pengubatan dan proses perubatan. Di samping itu, ritual ini melibatkan beberapa pemain muzik untuk memukul agong, bebendir dan debak.

Ironinya dalam hal ini, perubatan ritual Parinang ini tidak diketahui asal usul kewujudannya. Berpunca atau datang dari mana ilmu Parinang ini. Parinang ini saja dinyatakan sebagai sejenis rawatan pada zaman dulu dalam masyarakat Iranun dan Si Panai merupakan bomoh yang mengetuai upacara ritual ini. Disebabkan pada zaman dulu, pegangan masyarakat terhadap kepercayaan animisme itu terlalu kuat, maka mereka menganggap bahawa Si Panai ini merupakan pakar rawat atau doktor ketika itu.

Biasanya dalam ilmu perubatan ritual ini, amalan ilmu itu akan diturunkan kepada generasi ke generasi. Dekatnya, ilmu itu akan diturunkan kepada waris terdekat. Namun demikian, bagi etnik Iranun, ilmu ritual ini akan diperturunkan kepada individu yang sanggup menerima dan meneruskan amalan ini. Bukan itu sahaja, individu yang bakal menerima ilmu ritual ini hendaklah individu yang ikhlas, tidak pandai berbohong dan sanggup membantu orang lain tanpa mengharapkan imbalan yang diberi. Penulis sempat menemu bual salah seorang pengamal perubatan Parinang dalam etnik Iranun ini. Beliau dikenali sebagai Hj Musipar Imau, 80, menetap di Tapukan Kg. Rampayan Laut, Kota Belud. Beliau telah berkecimpung dalam perubatan ini selama 40 tahun. Dalam mempelajari ilmu perubatan ini, beliau telah berguru bersama dua orang guru yang berbangsa Iranun dan Melayu Brunei. Semasa perguruan, beliau mengatakan bahawa dalam mempelajari ilmu perubatan ini terdapat syarat-syarat yang perlu dipatuhi iaitu jangan berbohong, jangan mengumpat, jaga kebersihan diri, jaga solat dan hati ikhlas 
Sekiranya persyaratan semasa berguru ini tidak dipatuhi, maka ilmu yang dipelajari akan menjadi siasia dan ilmu itu akan memakan diri dengan cara merosakkan fikiran dan menggelapkan hati yang bersih. Justeru itu, beliau berpendapat untuk mempelajari ilmu ini bukan mudah dan bukan untuk mendapatkan populariti semata-mata tapi ikhlas untuk membantu orang yang memerlukan.

\section{Fungsi Perubatan Ritual Parinang}

Sudah terang lagi bersuluh dinyatakan bahawa ritual ini utamanya berfungsi untuk mengubati pesakit yang proses pengubatannya melibatkan alam ghaib atau mistik. Biasanya dalam hal ini, masih ada yang menganggap bahawa ritual ini hanya berfungsi untuk mengubati pesakit yang telah dirasuk oleh makhluk halus. Namun, ramai yang berpendapat bahawa ritual ini bukan sekadar berfungsi untuk mengubati pesakit yang telah dirasuk, tetapi boleh juga digunakan untuk mengubati penyakit-penyakit lain. Hal ini jelas seperti yang dinyatakan oleh informan Taim Hj Malampong (58) bahawa ritual ini boleh digunakan untuk menyembuhkan penyakit lain. Akan tetapi terpulang kepada jenis penyakit. Sekiranya penyakit itu memerlukan Bpangalai, makanya Si Panai akan melakukan ritual Parinang yang lengkap termasuk Bpangalai dan diiringi dengan paluan agung, bebendir dan debak. Sebaliknya jika penyakit si pesakit tidak memerlukan Bpangalai, maka ritual Parinang yang biasa dilakukan oleh Si Panai.

\section{Bahan-bahan yang diperlukan semasa menjalankan Ritual Perubatan Parinang}

Menurut Hj Musipar (80), biasanya dalam perubatan ini, si Panai akan menggunakan telur mentah, beras atau air putih untuk menjalankan perubatan ini. Rasional disebalik pemilihan bahan-bahan ini kerana bahan ini mudah didapati dalam masyarakat Iranun kerana masyarakat Iranun itu sendiri sebahagian besarnya menanam padi, memelihara ayam kampung dan menetap di tepi sungai atau laut. Sekiranya salah satu bahan ini tiada, maka Panai mempunyai pilihan untuk menggunakan salah satu daripada bahan utama ini.

Rajah 1: Senarai bahan utama yang digunakan dalam perubatan Parinang

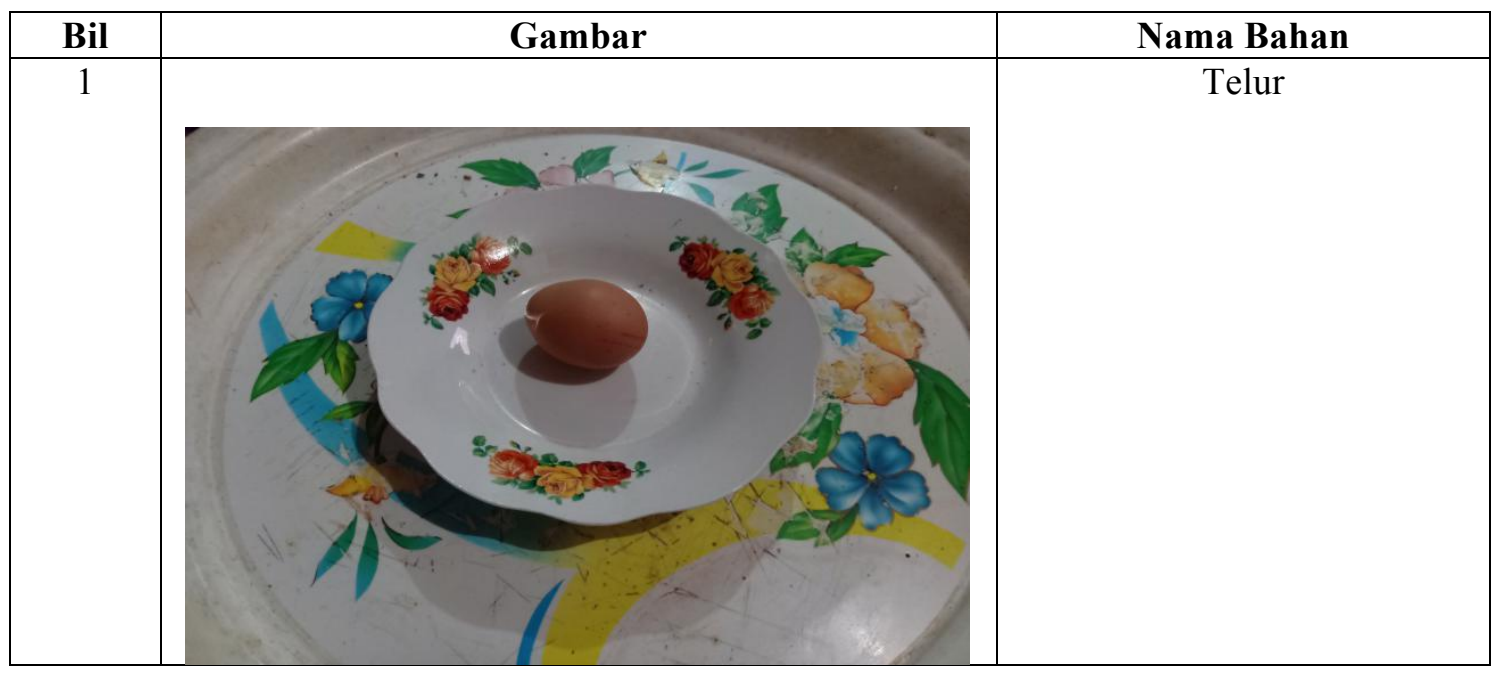



DOI: https://doi.org/10.47405/mjssh.v5i10.500

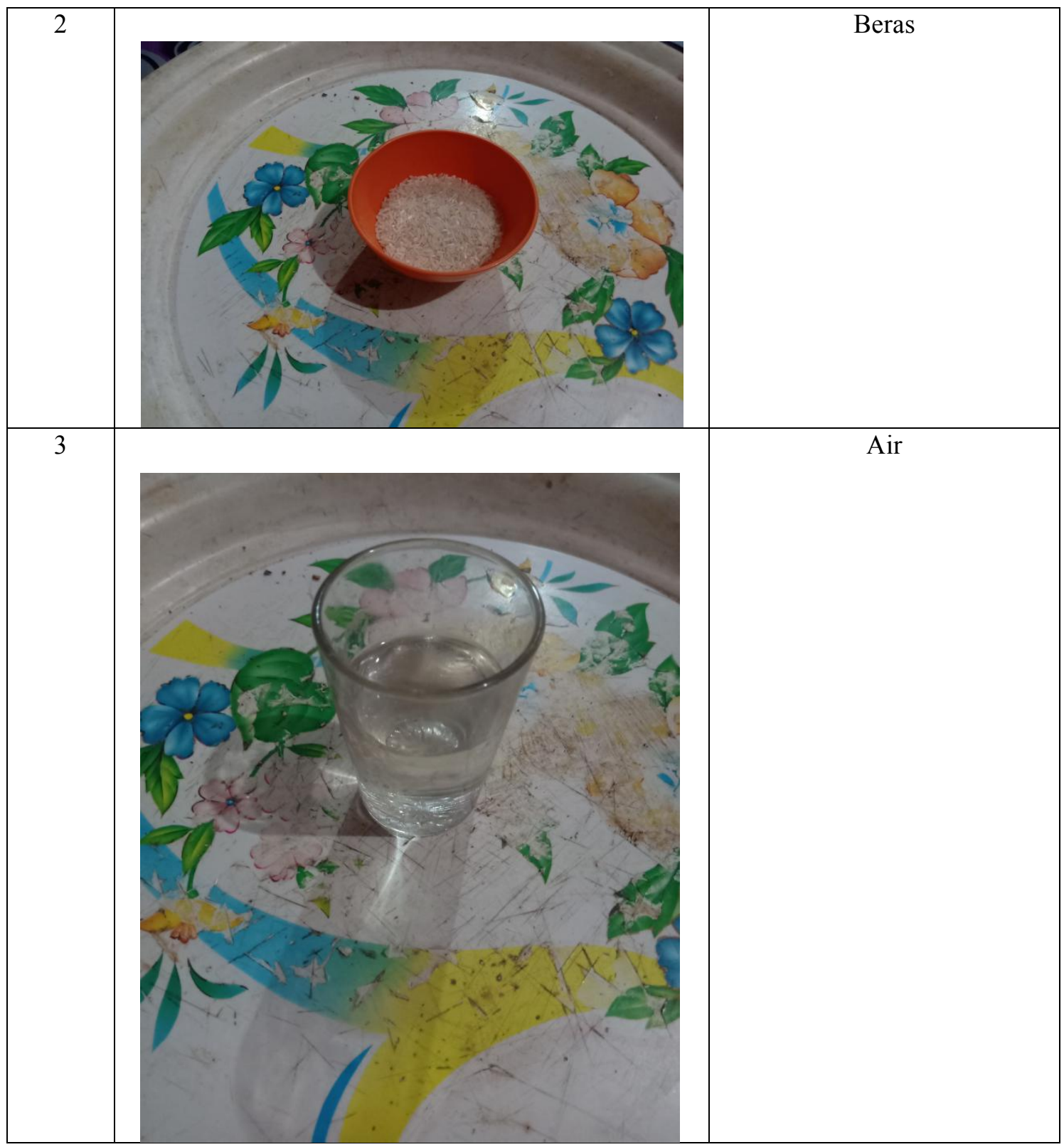

Rajah 2: Senarai bahan asas yang diperlukan dalam perubatan Parinang

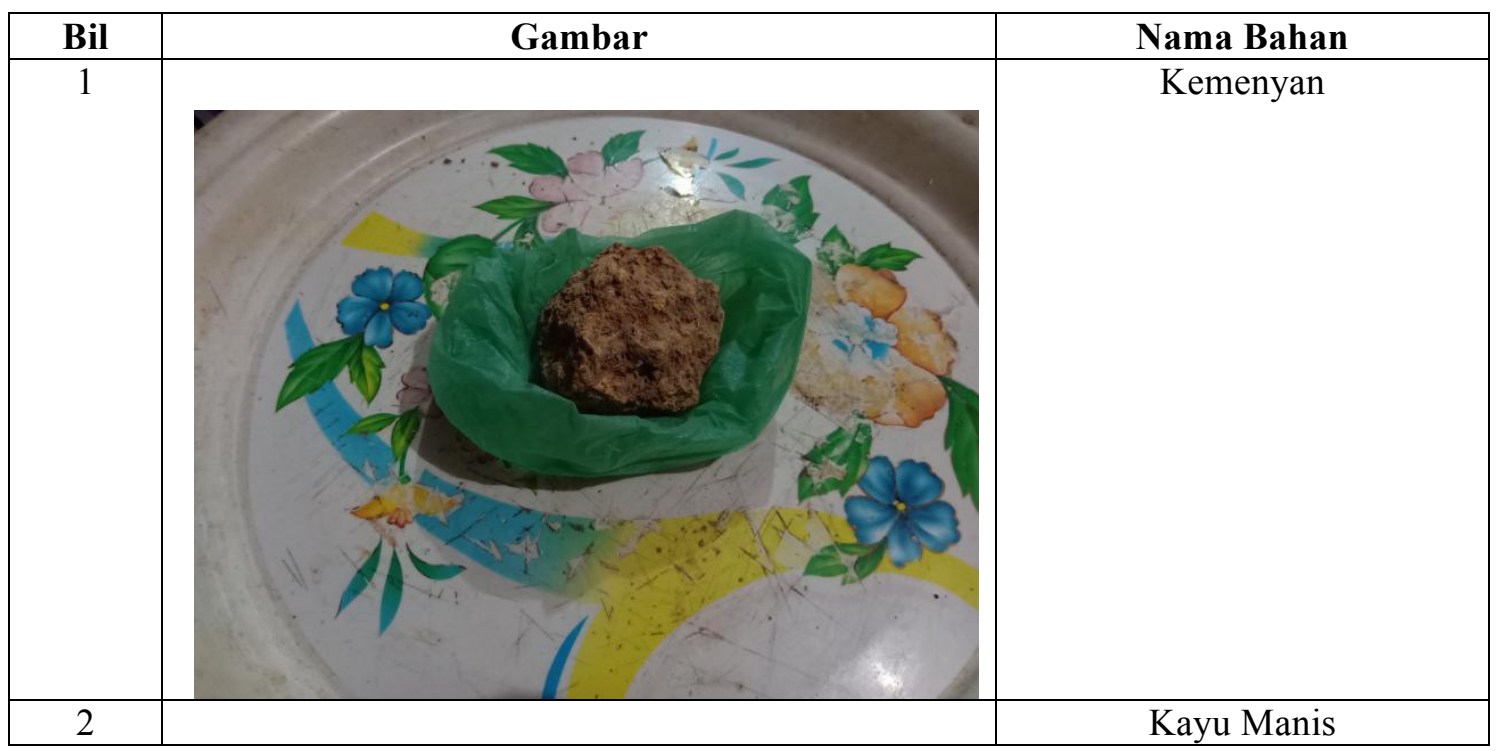


Malaysian Journal of Social Sciences and Humanities (MJSSH), Volume 5, Issue 10, (page 113 - 125), 2020

DOI: https://doi.org/10.47405/mjssh.v5i10.500

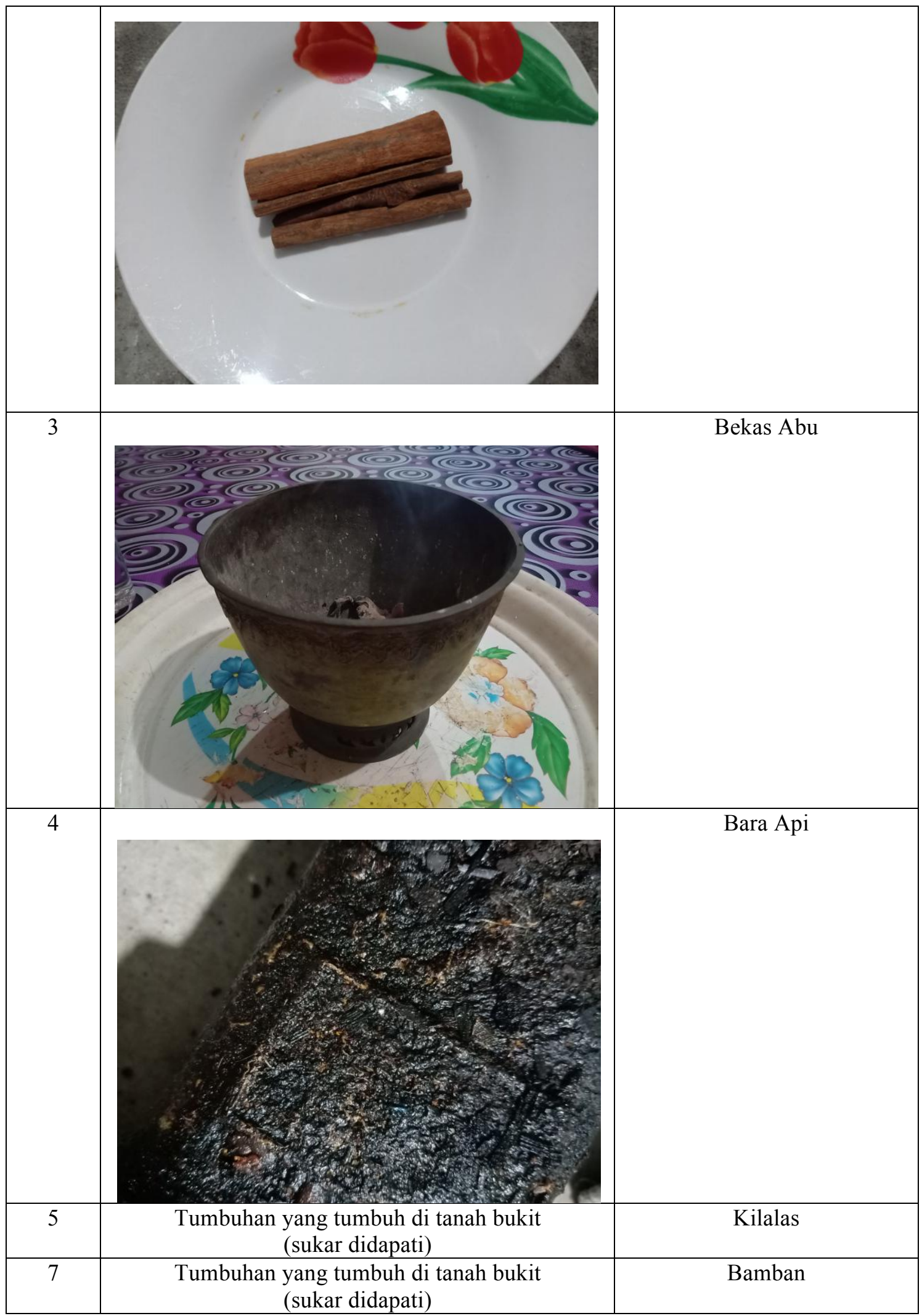




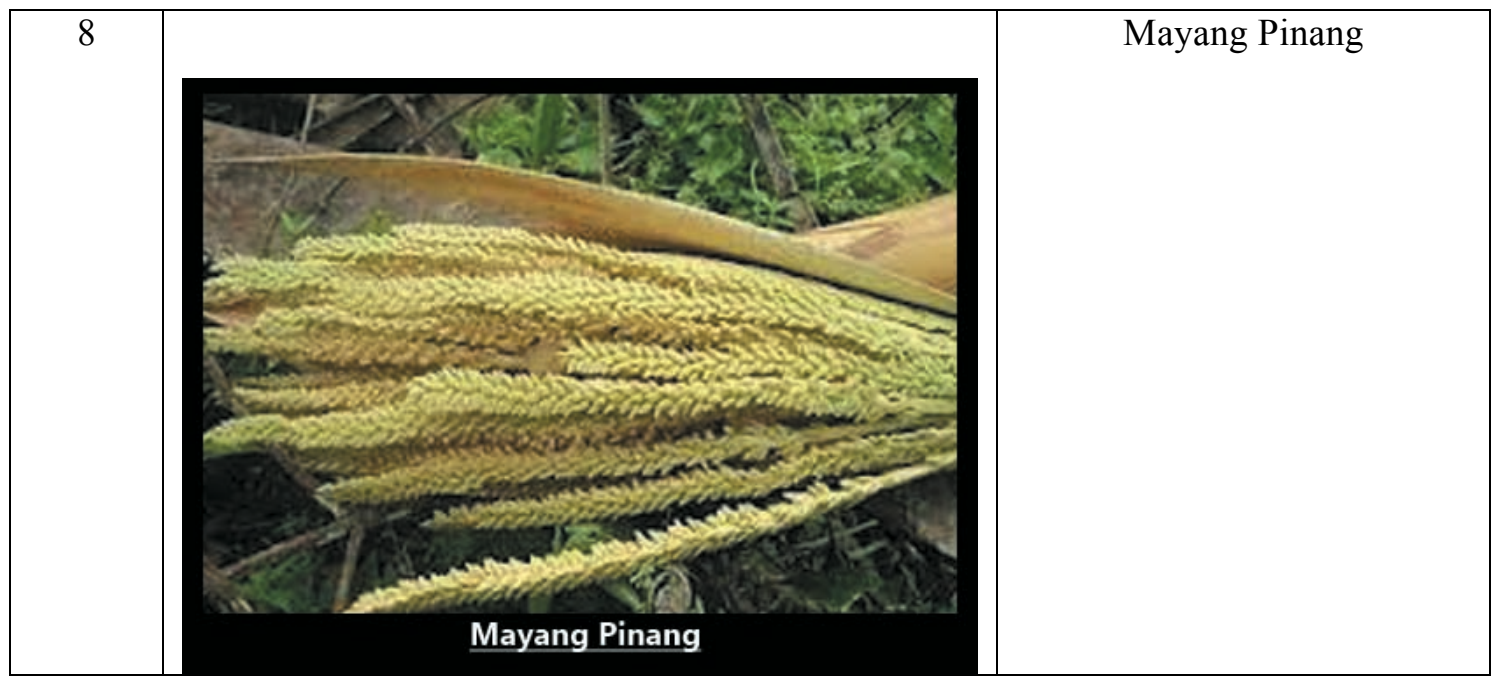

\section{Alat Muzik Ritual Perubatan Parinang}

Ritual perubatan parinang ini dilakukan dengan iringan paluan agung, bebendir dan debak. Dipercayai bahawa gabungan paluan ketiga-tiga alat muzik ini mampu menarik perhatian dan menaikkan semangat roh disamping bacaan mantera yang dibacakan ketika melakukan bpangalai. Irama paluan ketiga-tiga alat muzik ini berbentuk monotonous atau mendatar dan tahap kelajuannya semakin meningkat.

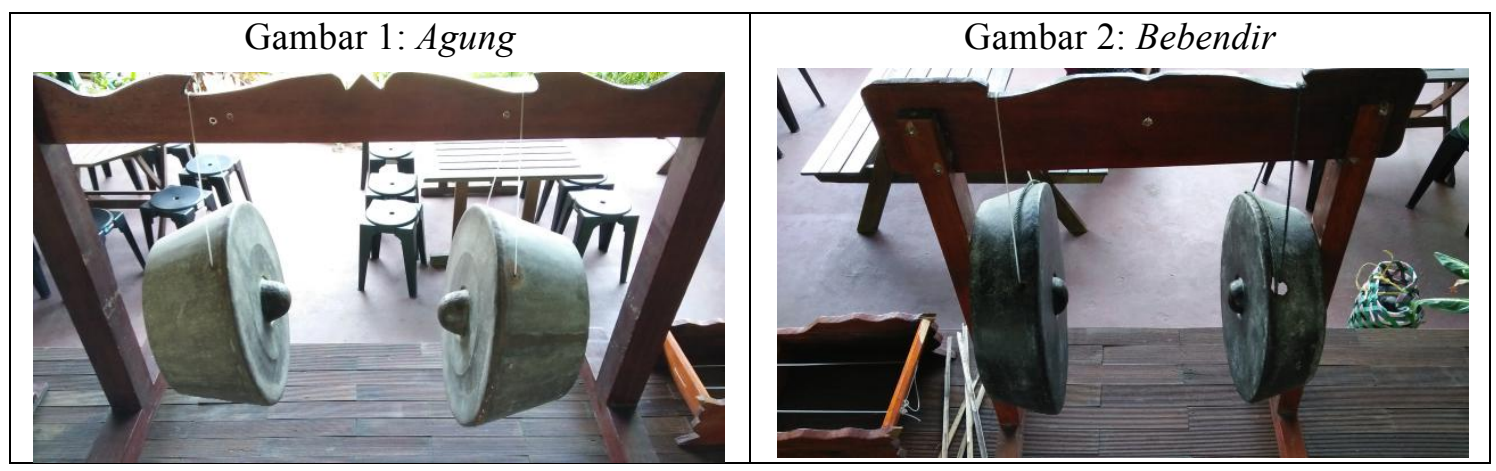

Gambar 3: Debak

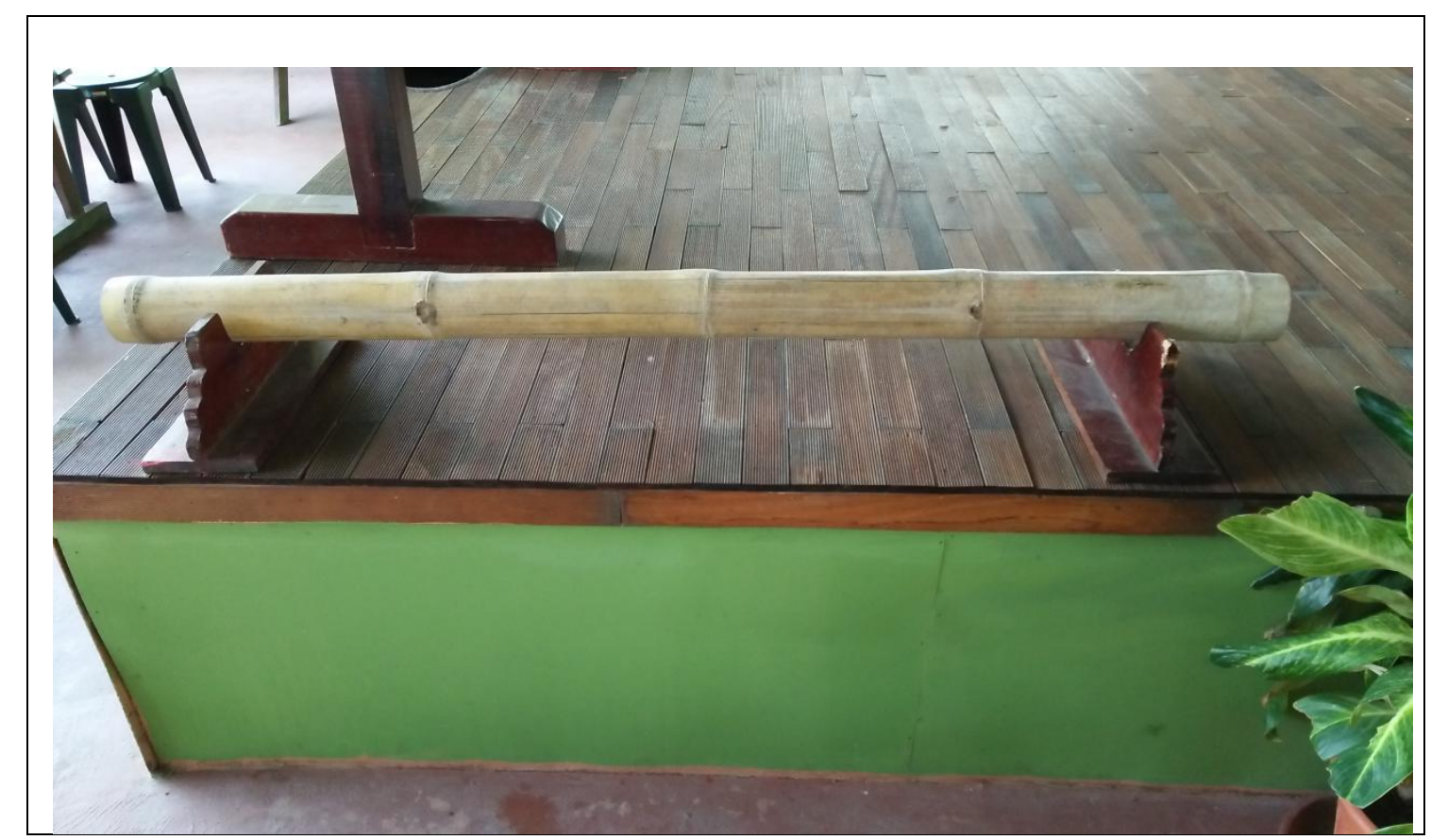


DOI: https://doi.org/10.47405/mjssh.v5i10.500

\section{Proses Pelaksanaan Perubatan Parinang}

\section{Peringkat Pertama}

i. Si Panai akan membuat persiapan terlebih dahulu dengan menyediakan segala bahan yang digunakan seperti dalam jadual 4.1 dan 4.2 sebelum memulakan ritual.

ii. Setelah selesai disediakan, Si Panai akan pergi mengambil wuduk.

iii. Apabila selesai mengambil wuduk, maka Si Panai akan duduk di tempat duduknya untuk memulakan perubatan ritual Parinang.

iv. Kalau menurut informan, sebelum Si Panai memulakan ritual, Si Panai akan membuat pemeriksaan ke atas badan pesakit menggunakan bahan yang dinyatakan pada jadual 4.1. Seperti yang telah dinyatakan, bahan tersebut terpulang kepada kecenderungan Si Panai untuk memilih bahan yang digunakan. Menurut Hj Musipar (informan), beliau cenderung menggunakan telur untuk memeriksa sakit si pesakit sebelum memulakan ritual.

v. Ketika ini, pesakit akan baring di ruang yang telah disedikan khas untuk pesakit. Ruangan itu dipanggil sebagai Sungkuban. Ruangan Sungkuban ini akan dihiasi dengan Mayang Pinang, Kilalas dan Bamban. Sungkuban ini merupakan ruangan makhluk halus yang diseru oleh Si Panai. Justeru itu, si pesakit diletakkan didalam ruangan Sungkuban tersebut.

vi. Pada peringkat ini, Si Panai akan memulakan ritual Parinang. Dalam ritual ini, Si Panai akan menyeru makhluk halus yang terlibat iaitu raja Binaning (raja kuning), raja Gadung (raja hijau), raja Maitem (raja hitam) dan langun a raja (semua raja). Menurut $\mathrm{Hj}$ Musipar Imau (informan), raja-raja yang diseru ini merupakan makhluk halus yang datangnya daripada keturunan Iranun terdahulu iaitu Raja Binaning keturunan Sharif, Raja Gadung keturunan Dato, Raja Maitem keturunan Pahlawan.

Gambar 4: Sungkuban

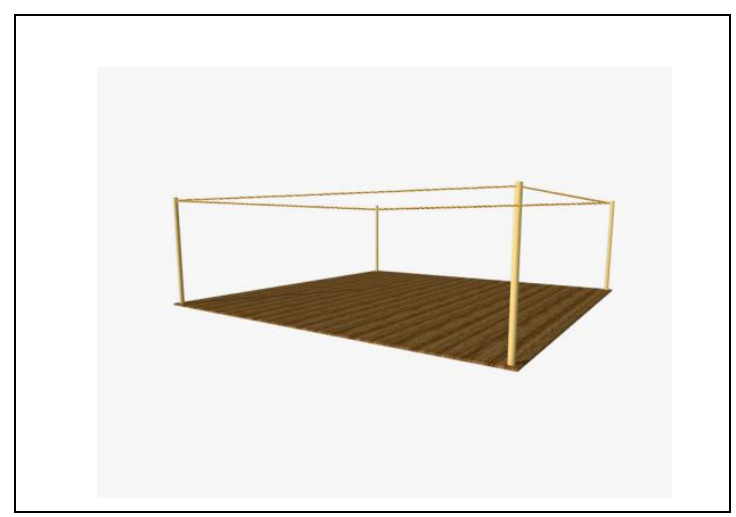


Malaysian Journal of Social Sciences and Humanities (MJSSH), Volume 5, Issue 10, (page 113 - 125), 2020 DOI: https://doi.org/10.47405/mjssh.v5i10.500

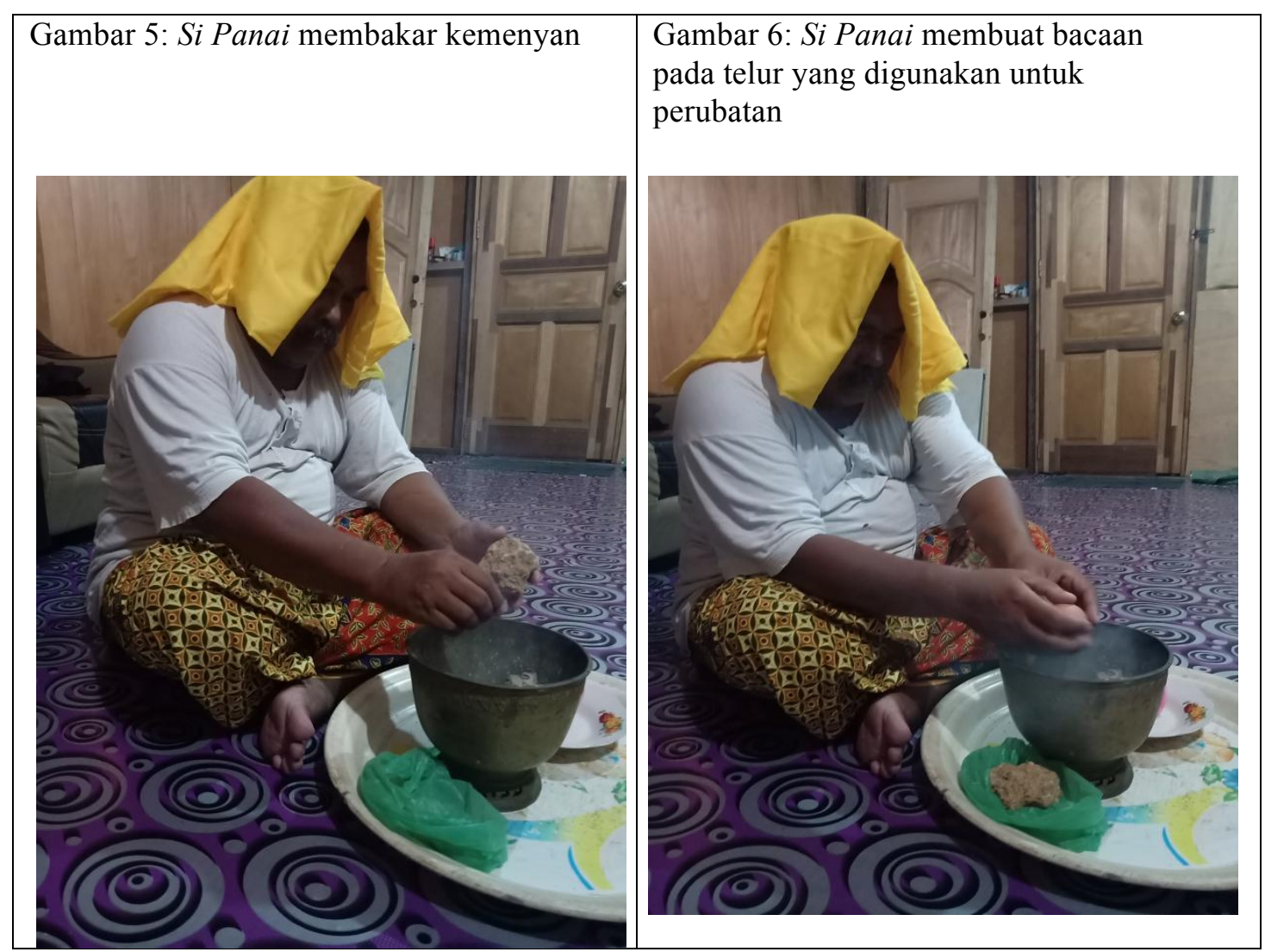

Gambar 7: Si Panai membuat tangas sambil membaca ayat-ayat kepada kain yang digunakan dalam ritual

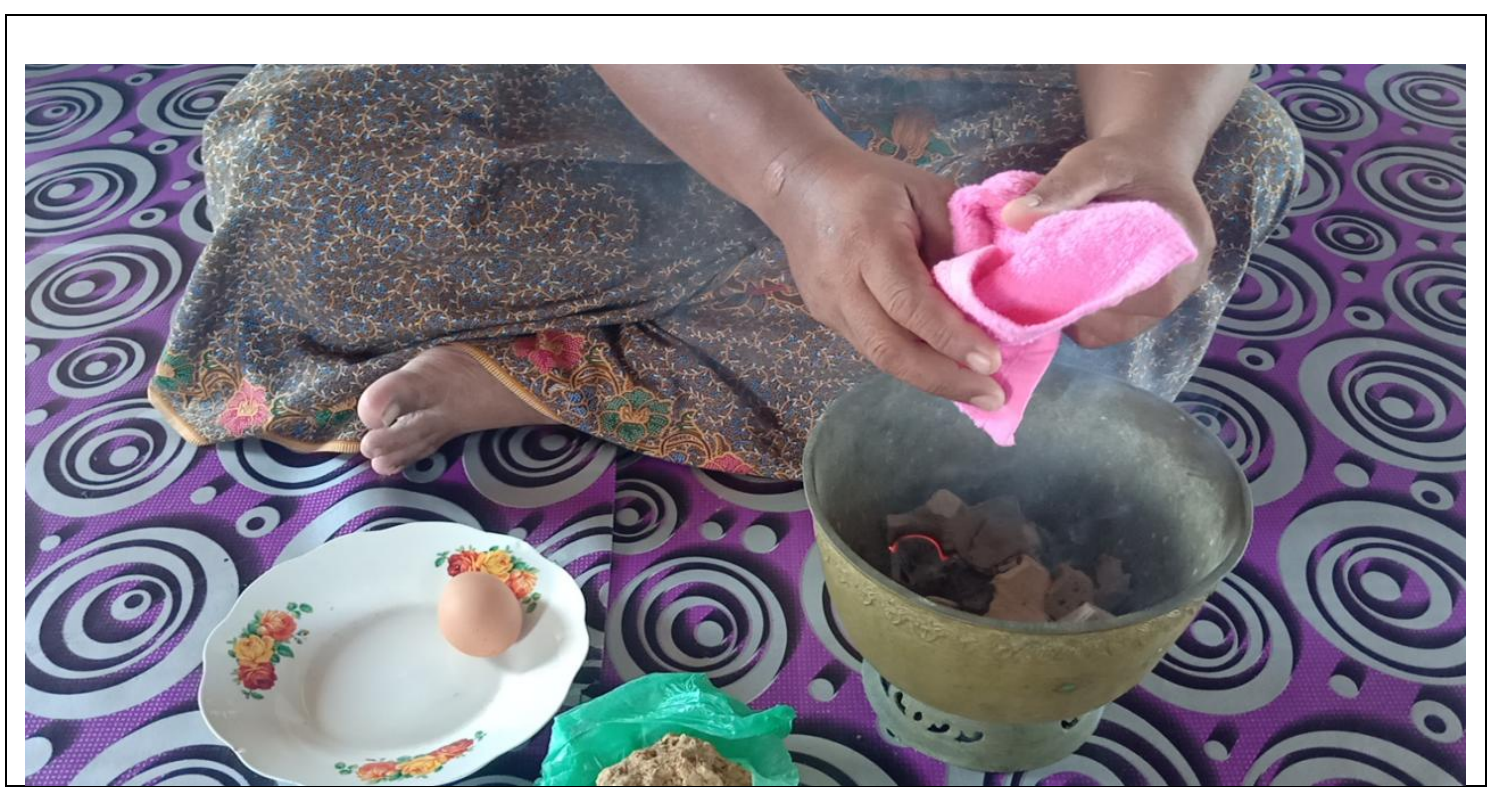




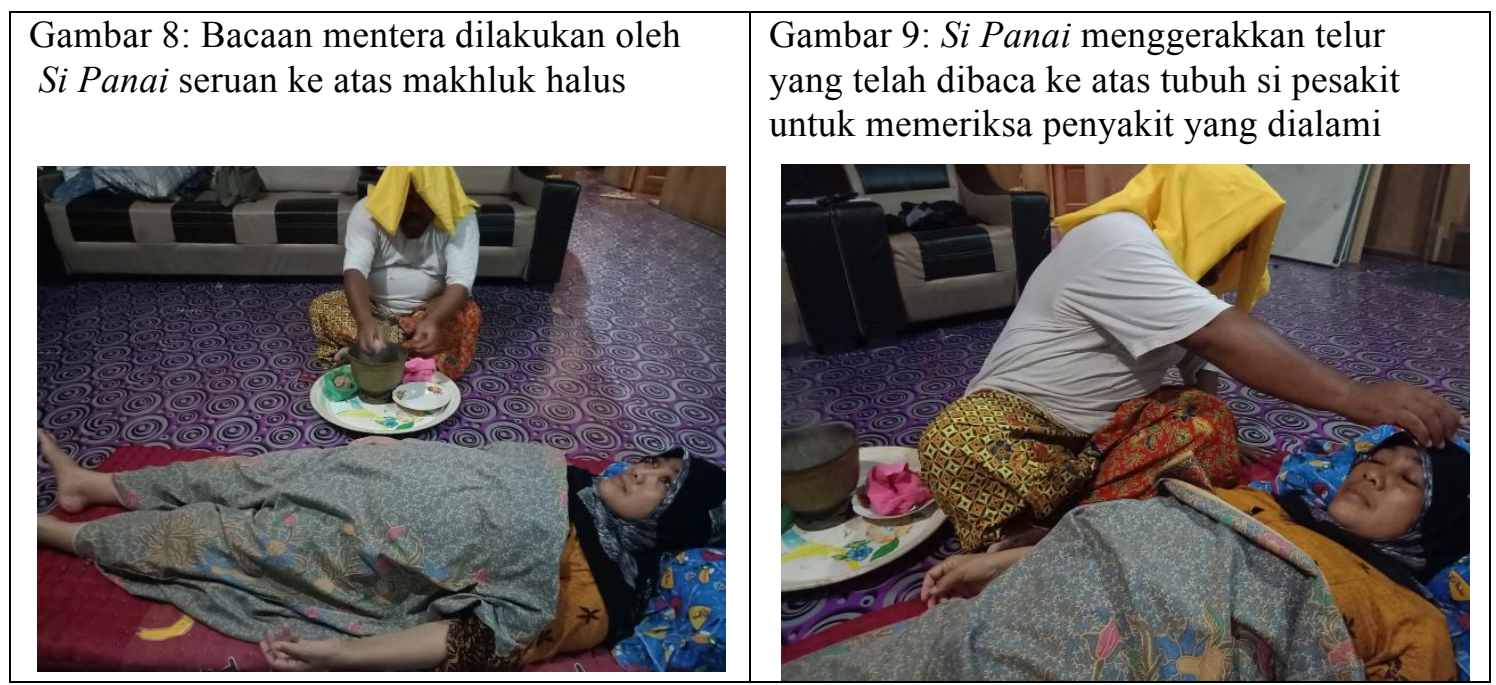

\section{Peringkat Kedua}

i. Di peringkat ini, setelah Si Panai menyeru makhluk halus tersebut, Panai tidak akan bertindak secara terus bersama makhluk yang diseru itu untuk mengubati pesakit.

ii. Si Panai akan bercerita bersama raja Binaning, raja Gadung, raja Maitem dan Langun a raja berkaitan sakit yang dialami oleh si pesakit.

iii. Si Panai akan bertanyakan kepada makhluk tersebut, apakah ubat yang sesuai untuk pesakit itu? Dan bagaimana cara pengubatannya?

iv. Dalam proses ini, Si Panai akan menjalankan tugasnya dengan bertanya pada makhluk tersebut tentang penyakit yang dialami oleh pesakit itu.

v. Sekiranya jawab makhluk tersebut memerlukan Bpangalai, makanya Si Panai akan membuat Bpngalai dengan mengelilingi si pesakit yang sedang baring.

\section{Peringkat Ketiga}

i. Dalam peringkat ini adalah proses Bpangalai itu dijalankan.

ii. Bpangalai ini dilakukan atas permintaan daripada makhluk yang diseru oleh Si Panai tadi.

iii. Proses Bpangalai ini bukanlah satu proses yang mudah. Kerana proses ini melibatkan tubuh Si Panai yang akan dirasuki oleh raja utama iaitu Raja Binaning. Raja Binaning ini akan menggunakan tubuh Si Panai untuk mengetuai perjalanan Bpangalai.

iv. Apabila Bpangalai ini dijalankan, Si Panai akan diiringi dengan muzik iaitu paluan Agong, Bebendir dan Debak. Alatan muzik ini dilakukan oleh pemain muzik yang khas bagi setiap alatan. Rentak muzik ritual ini rentak biasa yang hanya diketuk mengikut kepada Si Panai Bpangalai.

v. Disebabkan itu, menurut informan Taim Malampong (57), Si Panai tidak akan menyedari apapun yang dilakukan ketika itu. Si Panai akan mengensot kakinya dengan tangan sambil mengalai mengelilingi pesakit. Waktu itu ujar Taim Malampong (informan), Si Panai yang telah dirasuk itu mengelilingi pesakit dengan mengikut rentak beduk (alat muzik bambu). Semakin rancak Beduk dipalu, semakin rancak Si Panai mengensit kakinya mengelilingi pesakit dengan Bpngalai. Sekiranya Beduk itu dipalu dengan perlahan, maka rentak kakinya mengensot akan berubah menjadi perlahan.

i. Dalam proses Bpangalai ini juga, Si Panai akan menyapu sedikit kemenyan di badan pesakit bermula dari atas kepala, bahu kanan ke bahu kiri yang bertujuan untuk membenarkan kedua-dua makhluk halus tersebut memasuki badan pesakit.

vi. Si Panai (raja Binaning) seterusnya membaca mantera bermula dari atas kepala sehingga ke hujung kaki pesakit untuk menghilangkan penyakit yang dialami oleh pesakit tersebut.

vii. Proses Bpangalai ini akan terus berterusan sehingga penyakit pesakit itu semakin berkurangan. Bermaksud tiada ketetapan limit waktu untuk menjalankan proses Bpangalai ini. Hanya proses ini dilakukan sesuai antara pukul 08:00 malam. 
Malaysian Journal of Social Sciences and Humanities (MJSSH), Volume 5, Issue 10, (page 113 - 125), 2020 DOI: https://doi.org/10.47405/mjssh.v5i10.500
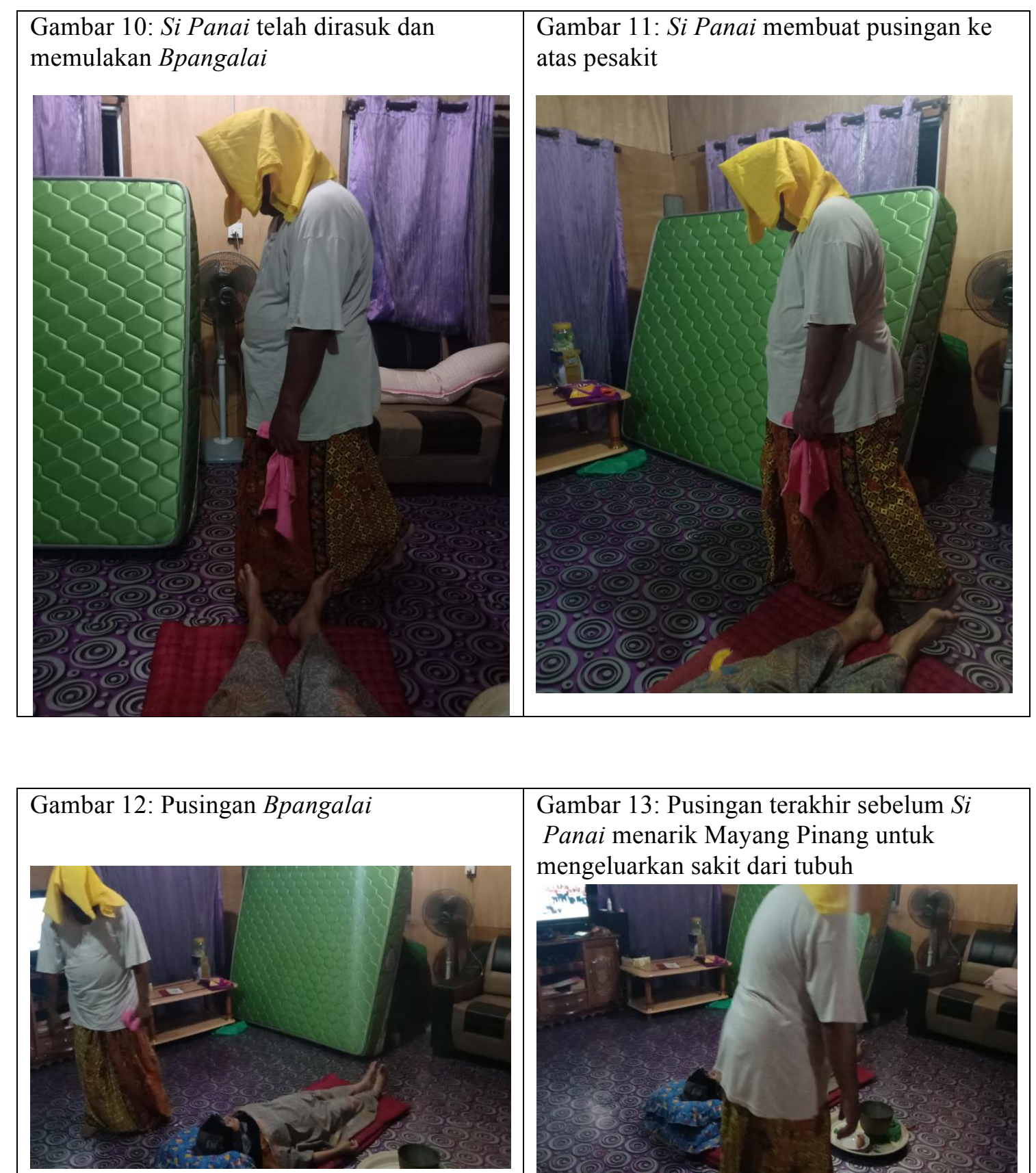

Gambar 13: Pusingan terakhir sebelum $S i$ Panai menarik Mayang Pinang untuk mengeluarkan sakit dari tubuh
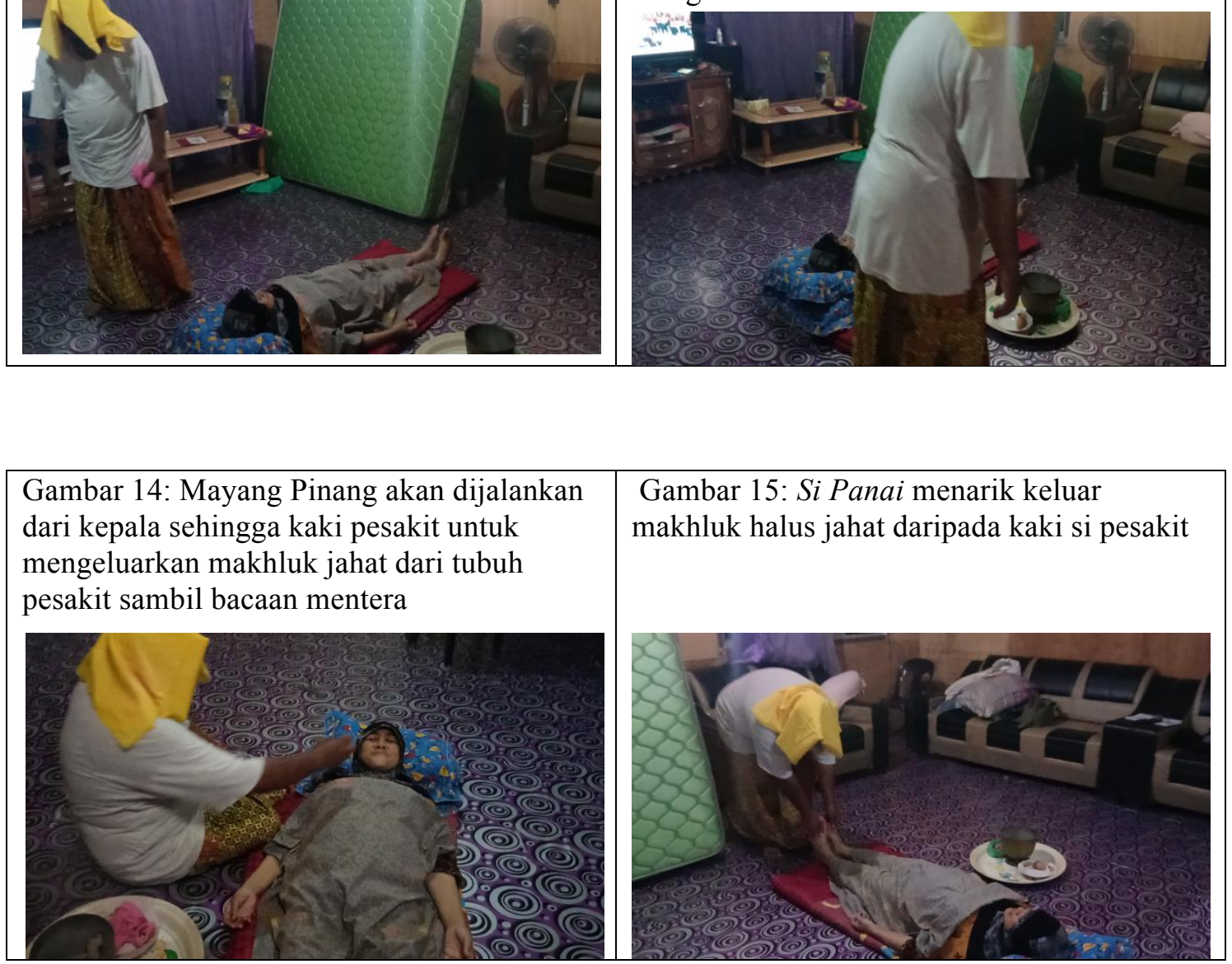


\section{Peringkat Keempat}

i. Proses ini akan dilakukan selama tiga malam berturut-turut. Informan mengatakan bahawa, sekiranya penyakit yang dialami oleh pesakit tersebut terlalu serius maka proses perubatan ini dijalankan selama tujuh malam.

ii. Sepanjang perubatan ini dilakukan, tidak kira sama ada selama tiga atau tujuh malam berturut, si pesakit hendaklah mematuhi segala pantang larang yang diberikan oleh $\mathrm{Si}$ Panai. Sekiranya si pesakit melanggar pantang larang maka perubatan ini akan menjadi sia-sia padanya.

\section{Peringkat Kelima}

i. Setelah selesai ritual perubatan, menurut Pn Rahmawati Hj Samad (60) satu upacara lagi dijalankan. Dalam masyarakat Iranun, upacara ini dikenali sebagai paganud sa a ajung (menghanyutkan Ajung).

ii. Ajung merupakan sebuah replika rumah yang dicipta khas untuk meletakkan juadah atau makanan sebagai pengeras untuk makhluk yang merasuk tubuh si pesakit.

iii. Ajung ini diperbuat daripada kain atau kertas. Tiang Ajung menggunakan kayu bambu. Kain atau kertas yang digunakan bewarna kuning. Pada setiap sudut bumbung Ajung tersebut akan diletakkan bendera warna merah, kuning, hijau dan hitam

iv. Ajung ini diletakkan di atas batang pokok pisang. Di dalam Ajung tersebut terdapat pelbagai jenis makanan seperti telur mentah, ayam hidup, beras, air dan apa sahaja yang menjadi keinginan makhluk yang merasuk itu. Setelah Ajung itu diisi dengan makanan tersebut, barulah Ajung ini dihanyutkan ke sungai.

v. Waktu yang sesuai untuk menghanyutkan Ajung ini ialah sekitar waktu petang pada jam 04:00petang. Ini disebabkan mengikut kepercayaan masyarakat Iranun, pada waktu petang turun penyakit sebaliknya pada waktu pagi naik penyakit.

vi. Masyarakat Iranun percaya bahawa Ajung tidak baik dihanyutkan pada waktu pagi.

Gambar 16: Ajung

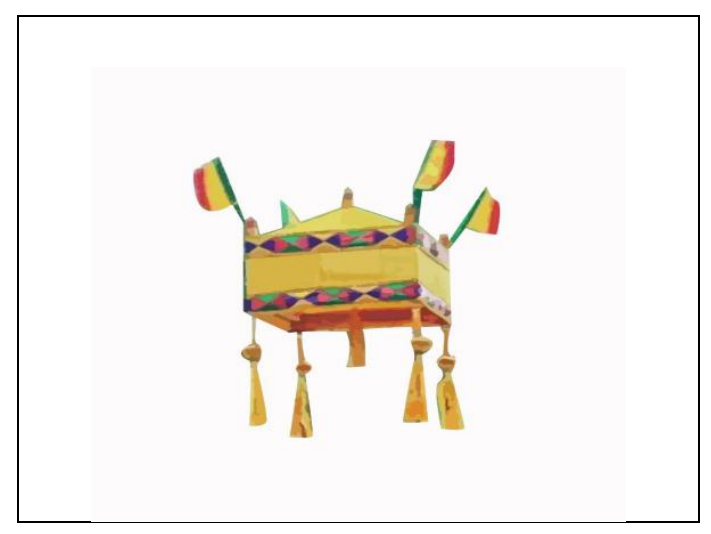

\section{Pantang Larang Perubatan Ritual Parinang: Panai, Pesakit dan Tetamu yang hadir}

\section{Panai}

i. Nawaitu atau niat hendaklah kerana Allah swt untuk membantu yang memerlukan.

ii. Jangan berbohong

iii. Jangan berlagak

iv. Jangan meminta bayaran tinggi (pengeras atau penghrgaannya hendaklah ikhlas)

v. Bersih daripada kekotoran (najis kecil). 


\section{Pesakit}

i. Nawaitu atau niat hendaklah ikhlas berubat.

ii. Jangan berlagak

iii. Beradab ketika hendak berubat

iv. Tidak memperlekehkan cara pengubatan.

v. Bersedia untuk menyediakan segala bahan yang diperlukan sepanjang pengubatan.

\section{Tetamu yang hadir}

i. Dilarang mengutuk atau mengumpat sewaktu pengubata dijalankan.

ii. Hendaklah dlam keadaan yang bersih ketika menghadiri upacara pengubatan dijalankan

iii. Dilarang mengejek perubatan yang dijalakan

\section{Kesimpulan}

Perubatan ritual masyarakat Iranun ini bertunjangkan kepada kepercayaan mereka terhadap alam metafizik serta ruang kosmos yang dikongsi oleh mereka dan mahkluk yang dari alam metafizik tersebut. Masyarakat Iranun ini percaya bahawa perhubungan dan keharmonian mereka antara dua alam ini harus sentiasa dipelihara untuk mengekalkan kesejahteraan dalam kehidupan kedua-dua alam tersebut. Sesungguhnya kepercayaan terhadap keseimbangan alam nyata dapat memberi kesejahteraan menjadikan perubatan ritual parinang berfungsi sebagai medium penyembuhan kerana dipercayai mampu mengembalikan keseimbangan yang nyata.

\section{Rujukan}

Datu’ Bandira Datu' Alang. (1992). Iranun: Sejarah dan Adat Tradisi. Kuala Lumpur: Dewan Bahasa dan Pustaka, Kementerian Pendidikan Malaysia.

Datu' Bandira Datu' Alang, Batua Al-Macaraya \& Howard McKaughan. (2002b). Iranun Traditional Narratives. (2). Howard McKaughan, Masrin Hassin \& Ismail Sidik (Eds.). Kota Kinabalu: Institut Linguistik (SIL).

Dennis J. Sading \& Siti Aminah Roslan (Ed.). (2017). Inventori Etnik Negeri Sabah: Etnik Iranun. Kota Kinabalu: Lembaga Kebudayaan Neger Sabah.

Dg. Suria Hj Mulia. (2010). Adat Kematian Suku Kaum Iranun Kota Belud. Dalam Saidatul Nornis

Hj Mahali: Adat dan Ritual Kematian di Sabah. Kota Kinabalu: Universiti Malaysia Sabah.

Ismail Ibrahim, Humin Jusilin, Zaimie Sahibil \& Mohd Pu'ad Bebit. (2018). Catatan Perjalanan Siri 1: Warisan Borneo. Kota Kinabalu: Universiti Malaysia Sabah.

Jacquelin Pugh-Kitingan. (2005). Acculturation at Kota Belud. Example From the Gong Ensemble Music of The Iranun, Bajau and Tindal Dusun. In Ismail Hj Ibrahim \& Jane Wong Kon Ling (Eds.). Warisan Seni Etnik Sabah. Prosiding Seminar Warisan Etnik Sabah 2002, 55-68. Kota Kinabalu: Pusat Penataran Ilmu dan Bahasa, Universiti Malaysia Sabah.

Lokman Abdul Samad \& Asmiaty Amat. (2012). Iranun. Dalam Katayya Mariappan dan Paul Paradong, Murut dan Pelbagai Etnik Kecil Lain di Sabah. Kota KInabalu: Universiti Malaysia Sabah.

Masrin Hj Hassin. (2001). Adat Istiadat Masyarakat Iranun. Kota Belud: Mahkamah Anak Negeri.

Saidatul Nornis Mahali. (2007). Kedatuan Sebagai Indikator Budaya Iranun dan Bajau di Sabah. Kota Kinabalu: Universiti Malaysia Sabah.

Sharifuddin Zainal, Mohd Kipli Abdul Rahman \& Mohammad Azizul Ibrahim. (2018). Jurnal Melabuh Ajung: Signifikasi Kepercayaan Kosmologi Dalam Pembentukan Identiti Teater Tradisional Etnik Pantai Timur Sabah. Gendang Alam, Jilid 8: 56. 